\title{
The Genre of Radical Thought and the Practices of Equality: the Trajectories of William Godwin and John Thelwall in the mid-1790s.
}

\author{
John-Erik Hansson
}

History and Civilization, European University Institute, Florence, Italy

John-Erik Hansson, Dept. of History and Civilization, European University Institute.

Villa Salviati, Via Bolognese 156, 50139, Florence, Italy

john-erik.hansson@eui.eu

The Version of Record of this manuscript has been published and is available in

History of European Ideas (published online: 9 May 2017).

http://www.tandfonline.com/doi/abs/10.1080/01916599.2017.1324803

In this paper, I approach the political and philosophical similarities and

differences between late eighteenth century thinkers John Thelwall and William

Godwin from the point of view of their respective choices for the genre of

political communication. I approach their thought and its expression by weaving

an interpretation of what they were saying with a reflection on how and to whom

they were speaking. This, I contend, helps us clarify further the thought of each

thinker and track the changes in their conception of equality in the framework of

political communication. As the 1790s unfolded, both thinkers, I argue, tried to

diversify their audience, be generally more inclusive, and re-think the hierarchies

of relationship between authors/speakers and their audience in their political

communication. Nevertheless, they did so asymmetrically and in different ways:

Thelwall quickly started tapping into popular culture, especially oral culture,

while Godwin chose the modes of fiction and the conversational essay. By

making these choices, both authors enacted a different understanding and practice

of political education, and political equality.

William Godwin, John Thelwall, Print Culture, Political Thought, Radicalism, Egalitarianism. 


\section{Introduction}

In December 1795, after 'a trifling incident when someone threw a stone at the King's coach, ${ }^{1}$ two harsh laws targeting radicals and reformers were enacted. They were the Seditious Meetings and Assemblies Bill, which restricted the freedom of association, and the Treasonable and Seditious Practices Bill, which curtailed the freedom of thought, speech, and the press. Their enactment marks the beginning of the demise of the radical movement that had developed in England - and particularly in London since the beginning of the French Revolution, galvanized as it was by the circulation of pamphlets such as Mary Wollstonecraft's Vindication of the Rights of Men (1790) and Thomas Paine's The Rights of Man (1791), both written as a response to Edmund Burke's inflammatory and conservative Reflections on the Revolution in France (1790). Not only did the bills give legal grounds for the state to swiftly crush radicalism, but they also led to fractures within the reform movement. These were famously embodied by the fallout between William Godwin and John Thelwall, two friends, political allies and notorious radicals, whose approaches to reform proved eventually incompatible for strategic reasons, and, as I shall argue, more philosophical reasons.

The Godwin-Thelwall controversy, as one might call it, breaks out with Godwin's anonymously written Considerations on Lord Grenville's and Mr. Pitt's Bills Concerning Treasonable and Seditious Practices, and Unlawful Assemblies. In that text, he tore asunder the logic of both acts. But the 'Lover of Order,' as he called himself in the pamphlet, also admonished the practices of radical lecturing and mass political

1 Boyd Hilton, A Mad, Bad, and Dangerous People?: England, 1783-1846 (Oxford; New York: Oxford University Press, 2006), 72. 
meetings. In doing so, Godwin specifically reprimanded his friend John Thelwall, who had been a leading orator of the London Corresponding Society (LCS), had spoken at the Copenhagen Fields mass meeting in October 1795, and had, up to that point, been some kind of a disciple of Godwinism. ${ }^{2}$ Godwin's criticism was viewed as a betrayal, as apostasy.

Thelwall, having guessed who the author of the pamphlet was, accused Godwin in the preface of the second volume of his Tribune of advancing 'the most extensive plan of freedom and innovation ever discussed by any writer in the English language' while admonishing 'every measure from which even the most moderate reform can rationally be expected. ${ }^{, 3}$ Later critics such as E. P. Thompson or Isaac Kramnick echoed these sentiments. All in all, Godwin was understood to have turned his back on reform, or at the very least to have become an objective ally of reaction before retreating from active participation in public affairs. ${ }^{4}$ While more recent and nuanced scholarship concerning this controversy has since appeared, it usually casts the Godwin-Thelwall controversy in terms of reformist political strategy without necessarily spending much

2 For a general history of radicalism in the 1790s, see: A. Goodwin, The Friends of Liberty: The English Democratic Movement in the Age of the French Revolution (Cambridge, Mass: Harvard University Press, 1979).

3 In Robert Lamb and Corinna Wagner, eds., Selected Political Writings of John Thelwall, 4 vols. (London: Pickering \& Chatto, 2008), vol. 2, 122.

4 See for example: Isaac Kramnick, 'On Anarchism and the Real World: William Godwin and Radical England,' The American Political Science Review 66, no. 1 (1972): 114-28; E. P Thompson, 'Benevolent Mr. Godwin,' in The Romantics: England in a Revolutionary Age (Suffolk: Merlin Press, 1997), 96-106; in contrast, see: John P. Clark, 'On Anarchism in An Unreal World: Kramnick's View of Godwin and the Anarchists,' The American Political Science Review 69, no. 1 (March 1, 1975): 162-67. 
time addressing what seem to me to be deeper, more substantial issues linking the two authors' political thought with their respective practice, namely issues related to hierarchy and power in communicative actions. ${ }^{5}$

My purpose in this paper is therefore to address this set of issues by unpacking the trajectories and dynamics of Godwin's and Thelwall's political thought between 1793 and 1797, particularly concerning the operationalisation of their shared broad egalitarianism. To do so, I propose to take seriously Iris Marion Young's observation that the choice of particular genre or mode of communication - for example, a book of philosophical reasoning or an allegorical story - is itself a political act grounded in

5 On the Godwin-Thelwall debate, broadly cast in terms of political strategy, see, for example: Andrew McCann, Cultural Politics in the 1790's: Literature, Radicalism, and the Public Sphere, Romanticism in Perspective (New York: St. Martin's Press, 1999), chapters 2 and 3; Jon Mee, Romanticism, Enthusiasm, and Regulation: Poetics and the Policing of Culture in the Romantic Period (Oxford ; New York: Oxford University Press, 2003 ) especially chapter 2; Jon Mee, Conversable Worlds: Literature, Contention, and Community, 1762 to 1830 (Oxford ; New York: Oxford University Press, 2011), chapter 3; Jon Mee, "The Press and Danger of the Crowd': Godwin, Thelwall, and the CounterPublic Sphere,' in Godwinian Moments from the Enlightenment to Romanticism, ed. Robert Maniquis and Victoria Myers (Toronto, ON.: University of Toronto Press, 2011), 83-102; Mark Philp, 'Godwin, Thelwall, and the Means of Progress,' in Godwinian Moments from the Enlightenment to Romanticism, ed. Robert Maniquis and Victoria Myers (Toronto, ON.: University of Toronto Press, 2011), 2011; Kenneth R. Johnston, Unusual Suspects: Pitt's Reign of Alarm and the Lost Generation of the 1790s, (Oxford: Oxford University Press, 2013) especially chapter 2. For slightly different takes on the debate, somewhat closer to my own, see: David O'Shaughnessy, 'Caleb Williams and the Philomaths: Recalibrating Political Justice for the Nineteenth Century,'NineteenthCentury Literature 66, no. 4 (2012): 423-448; Mary Fairclough, The Romantic Crowd: Sympathy, Controversy and Print Culture, 2013, 82-121. 
problems of inclusion and exclusion from the public sphere. ${ }^{6}$ In other words, I want to complement the analysis of what the thinkers were saying, by examining more closely how and to whom they were saying it. By doing this, I show that Godwin and Thelwall both begin, in the early 1790 s, by solely appealing to a middle class, well-educated audience despite their professed egalitarianism, following their understanding of the ability of the broader British public to exercise their capacities for moral and political reasoning. ${ }^{7}$ Soon after, however, they reconsider this view, and thus try to resolve some of the tensions between this egalitarianism and this initial bias by experimenting with, and building on different existing political and literary traditions of British culture. Both thinkers, I argue, tried to diversify their audience, be generally more inclusive, and to re-think or re-calibrate, through their political communication, the relationship between authors/speakers and their audiences.

The internal tensions of both authors' political thought, as well as their attempt to resolve them emerge at the intersection of two broader historical developments. The first is simply the growing repression of reformist activity, leading to the eventual demise of the reform movement, 'crushed,' as it was, 'by state directed coercion." Repression took both legal and para-legal forms, and John Thelwall was at the receiving end of both: he stood as one of the accused during the infamous Treason Trials of 1794, and saw his lecture attacked, and his life threatened, by a Church and King mob at

6 See chapter 2 in Iris Marion Young, Inclusion and Democracy (Oxford University Press, 2002).

7 I am grateful to the anonymous reviewer who helped me clarify - and indeed formulate this point.

8 Mark Philp, Godwin's Political Justice (Ithaca, N.Y.: Cornell University Press, 1986), 173. 
Yarmouth in 1796, as he more or less subtly defied the 1795 Seditious Meetings, and Treasonable Practices Acts, also known as the Gagging Acts of $1795 .{ }^{9}$ The second historical development in the context of which we can understand Godwin's and Thelwall's activity in the mid-1790s is the growth of a British political public. This is visible in the large consumption of political material by individuals from all walks of life, made possible by the increasing availability of political material thanks to productive printing presses, as well as rising levels of instruction and literacy, and the development of a language of politics that was accessible to popular audiences. ${ }^{10}$ All of this fostered a more democratic kind of political exchange among members of the British public, even though it also fragmented the public following lines drawn in an increasingly polarised political environment. ${ }^{11}$

By recasting Godwin's and Thelwall's works of the 1790s in these intersecting contexts, and foregrounding the relationship between an intervention, its (political) purpose, and its audience, I show first how tensions in Godwin and Thelwall's broad

9 On this, see for example: Goodwin, The Friends of Liberty, especially chapters 8-10; Hilton, A Mad, Bad, and Dangerous People?, 69-74, part II of John Barrell, Imagining the King's Death: Figurative Treason, Fantasies of Regicide, 1793-1796 (Oxford ; New York: Oxford University Press, 2000), as well as part I in Johnston, Unusual Suspects. On the repression of Thelwall more specifically, see: E. P. Thompson, 'Hunting the Jacobin Fox,' Past \& Present, no. 142 (February 1, 1994): 94-140.

10 Olivia Smith, The Politics of Language, 1791-1819 (Oxford: Clarendon Press, 1984), 35; William Stafford, Socialism, Radicalism, and Nostalgia: Social Criticism in Britain, $1775-$ 1830 (Cambridge: Cambridge University Press, 1987), 29.

11 Marilyn Butler, Burke, Paine, Godwin, and the Revolution Controversy (Cambridge: Cambridge University Press, 1984), 185; Jon P Klancher, The Making of English Reading Audiences, 1790-1832 (Madison, Wis.: University of Wisconsin Press, 1987), 19-26. 
egalitarianism emerge already in 1793, and how they are related to the genre choices they make (section 2), before turning to the crucially different ways in which both authors try to resolve these tensions (sections 3 and 4). Thelwall quickly started tapping into popular culture, and developed a particularly effective mix of print and oral culture, while Godwin chose the modes of fiction and the conversational essay. These different choices led, in the case of Thelwall, to the inclusion of the lower classes at the expense of a problematic hierarchical relationship between the orator and his audience, while Godwin chose instead to bring about a more balanced author-reader relationship, without seeking to extensively include individuals from the lower classes.

\section{In the Year 1793}

The year 1793 was something of an annus mirabilis for William Godwin and John Thelwall. The former published the first edition of the Enquiry Concerning Political Justice, which would bring him to fame as a radical thinker, in February. Soon after, he wrote an important number of public letters for the Whig-oriented Morning Chronicle, where he dealt with the burning issue of the legal repression of radicals and reformers. John Thelwall delivered as a lecture, and subsequently brought out, the Essay Towards a Definition of Animal Vitality at the January meeting of the Physical Society in London, and published an unconventional political novel, The Peripatetic. While all of these are genuinely radical in their own ways, a closer analysis nevertheless reveals some tensions in the thoughts of their authors, apparent in the disjoint between a radical egalitarianism and an exclusionary practice of political communication. 
On the surface and in many of its doctrines, the Enquiry Concerning Political Justice appears as a radically egalitarian work. Godwin relentlessly defends the moral equality of individuals, and the fundamental need for the exercise of each and everyone's private judgment, two beliefs which he holds at least until the third edition of the work. ${ }^{12}$ It is with this in mind that we should consider Godwin's preface to the book, where he notes that he was 'desirous of producing a work from the perusal of which no man should rise, without being strengthened in habits of sincerity, fortitude and justice. ${ }^{13}$ Moreover, following what Mark Philp has described as a 'highly democratic' and 'essentially non-individualist' view of truth, which requires the active participation of different individuals, Godwin sought to initiate a broader philosophical debate with his work, and, through the 'collision of mind with mind,' discover fundamental political truths. ${ }^{14}$ However, Political Justice was, by its price, style and

12 The standard scholarly edition of the Enquiry Concerning Political Justice is to be found in the third and fourth volumes of William Godwin, Political and Philosophical Writings of William Godwin, 7 vols. (London: Pickering, 1993), published under the general editorship of Mark Philp. Volume 3 contains the text of the first edition, while volume 4 tracks the revisions Godwin made in the two subsequent editions of 1796 and 1798. For the brevity's sake, I refer to this work in footnote, using the pagination of the aforementioned edition, in the following way: Godwin, Political Justice (1793), followed by page numbers. On equality, see Ibid., 10-13, and especially 63-65. On the right and necessity of private judgement, see Ibid., 70-82. In Godwin's Political Justice, Mark Philp shows these broad continuities throughout the editions of the text. For another discussion on Godwin's egalitarianism and its relation with social change, see John P. Clark, The Philosophical Anarchism of William Godwin (Princeton, N.J: Princeton University Press, 1977), 71-76, 274.

13 Godwin, Political Justice (1793), iii. Emphasis added.

14 Ibid., 15; Philp, Godwin's Political Justice, 128. 
subject, and even in the author' own judgment, 'by its very nature an appeal to men of study and reflection.' And indeed, this was, in Godwin's mind, the audience that could effectively participate in what he describes as the 'collision of mind with mind', or the only way through which truth could 'infallibly be struck out' before being disseminated more broadly in society. ${ }^{15}$ In other words, Godwin wrote a book he thought would benefit all its readers regardless of their position in society, and making them partake in the elaboration of truth in conversation, and yet, the book's circulation was limited not only because of its cost and format, but more crucially because of the tone and genre the author chose.

This tension is a consequence of Godwin's understanding of the development of human intellect and morality in relation to the institutions of society. For Godwin in 1793, children are brought into the world as blank slates; there are no innate principles of morality or action. ${ }^{16}$ Through individual experience, structured by institutions and social habits, children acquire virtues, vices and prejudices, all of which are continually reinforced in society. Prejudices and vices are then particularly difficult to displace in 'the multitude' as they do not 'have the leisure for reasoning and reflection', and therefore 'cannot partake' in the 'illuminations' of 'that literature by which prejudice is superseded. ${ }^{17}$ Given, then, that for Godwin members of the labouring classes cannot actually reason - even if that is not their fault, but rather that of a corrupt society, they cannot be part of the conversation through which truth emerges. At best they can be on

15 Godwin, Political Justice (1793), iii-v.

16 Ibid., 10-13.

17 Ibid., 16. 
the passively receiving end of truth after it has effectively been found. Godwin therefore begins with egalitarian principles, the operationalisation of which is conditioned by the social theory he develops concerning the rational abilities of the broader public given a set of existing conditions and institutions. This, then, justifies the elitism embodied in the format, style, and the 'very nature' of the Enquiry Concerning Political Justice.

It may be argued, however, that Godwin's intended reading public exceeded that of the Enquiry Concerning Political Justice. The audience of the various letters Godwin published in the Whig-oriented Morning Chronicle, for instance, was more mixed. ${ }^{18}$ Still, Godwin's audience there would still have mainly consisted of middle and uppermiddle class individuals, in contrast, for example, with the audience of Daniel Isaac Eaton's Politics for the People, initially playfully entitled Hog's Wash, to which we will return below. Furthermore, while the public character of these letters cannot be denied, their official addressees were members of the upper middle-classes, or the political establishment. They include the editor of the Morning Chronicle himself, John Reeves, a former Chief Justice of Newfoundland and chairman of the loyalist Society for Protecting Liberty and Property Against Republicans and Levellers, or in the case of Godwin's third 1793 letter, 'such persons as may be appointed to serve upon juries for the trial of seditious and treasonable words. ${ }^{19}$ To put it succinctly, regardless of whether

18 Reprinted as letters 2-6 of the 'Political Letters 1791-4', in Godwin, Political and Philosophical Writings of William Godwin vol. 2, pp. 12-30.

19 Godwin, 'Letter 5', Ibid., 24. On the class composition of juries, see: Douglas Hay, 'The Class Composition of the Palladium of Liberty: Trial Jurors in the Eighteenth Century,' and P. J. R. King, “Illiterate Plebeians, Easily Misled': Jury Composition, Experience, and Behavior in Essex, 1735-1815,' both in Twelve Good Men and True: The Criminal Trial Jury in England, 1200-1800, ed. J. S. Cockburn and Thomas A. Green (Princeton, NJ: 
Godwin writes a book of philosophy, or an open letter, his egalitarian doctrines are addressed to members of the educated élite.

John Thelwall's 1793 works seem to me to be characterised by a similar tension. His first significant act of political (and scientific) communication is the Essay Towards a Definition of Animal Vitality. In it, he defends a materialist understanding of life, against the 'vitalist' position of John Hunter and much of the medical profession, which he associates with religious superstition. As Yasmin Solomonescu has recently shown, this challenge to the commonplaces of the late eighteenth century medical profession mirrors and informs Thelwall's criticism of the political status quo as well as his desire for radical reform. ${ }^{20}$ However, the scientific subject and indeed the very nature of the debate, as well as the location and occasion for the utterance - the monthly meeting of the Physical Society - suggest a generally middle-class, highly educated audience, and an exclusionary setting.

Thelwall reached out to the very same audience with his longest and most explicitly political work of 1793: The Peripatetic. This book is a peculiar and somewhat ambiguous work that resists strict generic categorisation by mixing a variety of genres, popular and polite, which serves to level the arbitrary distinctions between them. Accordingly, in the preface to the novel, Thelwall claims that it is by 'design' meant to be 'uniting the different advantages of the novel, the sentimental journal and the

Princeton University Press, 1988), 305-57 \& 254-304 respectively.

20 Yasmin Solomonescu, John Thelwall and the Materialist Imagination (Basingstoke: Palgrave Macmillan, 2014), especially chapter 2. A briefer account of this connection is also given in Fairclough, The Romantic Crowd, 108-111. 
miscellaneous collection of essays and poetical effusions. ${ }^{21}$ As a consequence, Judith Thompson describes The Peripatetic as an 'exercise in applied genre theory,' in which Thelwall, by self-consciously choosing to mix genres and publicising it as his 'design', challenges the existing norms governing the writing and publication of literature and suggests that one can produce, by combining the 'advantages' offered by different genres, a work of higher quality than one limited by traditional literary conventions. ${ }^{22}$ This exercise in the mixture of genres has also illuminatingly been related back to the development of Thelwall's political thought, and its underlying principle of egalitarianism. In Thompson and Solomonescu's view, the displacement of arbitrary generic distinctions foreshadows and embodies Thelwall's critique of social distinctions among individuals, also brought to the fore in the novel through the various encounters of Sylvanus Theophrastus, the narrator of The Peripatetic. ${ }^{23}$

However, while Thelwall criticises arbitrary distinctions of rank, he shares with Godwin a firm conviction that such distinctions have the effect of fundamentally determining the thoughts and actions of lower-class individuals in society, which generates a tension in his egalitarianism. The encounter between Sylvanus Theophrastus

21 John Thelwall, The Peripatetic, ed. Judith Thompson (Detroit: Wayne State University Press, 2001), 72.

22 Judith Thompson, “A Voice in the Representation': John Thelwall and the Enfranchisement of Literature,' in Romanticism, History, and the Possibilities of Genre: Re-Forming Literature, 1789-1837, ed. Tilottama Rajan and Julia M. Wright (Cambridge: Cambridge University Press, 1998), 124-125.

23 Ibid.; Yasmin Solomonescu, 'Articulations of Community in The Peripatetic,' in John Thelwall: Radical Romantic and Acquitted Felon, ed. Steve Poole (London: Pickering \& Chatto, 2009), 83-93. 
and a Scottish sailor is edifying on that point. After Sylvanus initiates a conversation with him, the Scottish sailor ventures to identify the protagonist's profession and guesses 'tradesman.' This being a mistake, Sylvanus corrects it. However the manner in which Sylvanus responds to the sailor unwittingly thwarts 'that freedom of conversation from which alone the human heart can be revealed. ${ }^{, 24}$ Sylvanus's curtness 'spontaneously' excited in the Scotsman 'the slavish impression of these supposed distinctions' of rank or birth..$^{25}$ The immediate consequence is that free communication is suspended, which prevents the emergence of a natural and equal conversation desired by Sylvanus Theophrastus, and by Thelwall himself. In effect, the narrative undermines the existence of traditional distinctions, but divides individuals anew, this time according to their level of education, class position, and a related capacity for sympathy, feeling.

We therefore have, first, Sylvanus Theophrastus, the protagonist and narrator who is in the position of the feeling observer, and second, those characters who are undeniably part of the (uncultured and uneducated) masses - such as the Scottish sailor - and lack the agency to break free from the prejudices in which they were socialised. Thus the poor are only exceedingly rarely allowed to represent themselves as 'politically knowledgeable characters speaking an adequate language.' ${ }^{26}$ This is the case even though they may be like the sailor of The Peripatetic: gifted with 'an intelligent

24 Thelwall, The Peripatetic, 97.

25 Ibid.

26 Smith, The Politics of Language, 1791-1819, 87 
mind,' a certain courage and, 'so frank and honest a heart. ${ }^{27}$ In short, while the novel advances an egalitarian ideal, it is only knowledgeable and sympathetic characters such as Sylvanus Theophrastus who can make use of their agency, in contrast to those characters - usually of the lower orders of society - who almost by definition cannot become true agents. ${ }^{28}$

This tension is exacerbated, and can indeed be characterised in further detail, given the intended audience of Thelwall's book. As Michael Scrivener notes, the novel's 'ambiguous status as both popular and polite is embodied materially in its very publication:' the price of the novel was 9 shillings, well above the means of an average labourer, though not as expensive as, for example, Godwin's Political Justice. ${ }^{29}$ Moreover, as Judith Thompson remarks, the work's 'literary and historical allusions, genial tone, and elaborate ironies seems more obviously addressed to educated, genteel readers than to the artisan classes whom Thelwall roused with fiery oratory in 179596. ${ }^{30}$ The comparison with Thelwall's later political activity is particularly welcome, as the choice of the oratory in the form of the lecture, and cheap-print formats, as well as Thelwall's increasing engagement with popular genres suggest that he might well have identified this tension in his earlier work and tried to overcome it by changing audiences

27 Thelwall, The Peripatetic, 97-98.

28 On this point, see also: Thompson, “A Voice in the Representation': John Thelwall and the Enfranchisement of Literature,' 137-138.

29 Michael Scrivener, Seditious Allegories: John Thelwall \& Jacobin Writing (University Park, Pa.: Pennsylvania State University Press, 2001), 211.

30 Thompson, “A Voice in the Representation': John Thelwall and the Enfranchisement of Literature,' $147 \mathrm{n} 15$. 
and engaging in mass popular education. Nevertheless, the intended audience as well as the form and content of The Peripatetic (and the very existence of the Essay) indicate that, in 1793, Thelwall's energy was spent trying to convince the members of the educated and relatively well-off classes of the necessity and desirability of reform. Further, much like Godwin, he seems to have thought that it was only or mainly through these circles that reform was indeed possible.

\section{Thelwall's Reorientation: Popular Print and Oral Cultures}

After joining the London Corresponding Society in late 1793, and building on his experience as an active member of the Coachmaker's Hall Society for Free Debate, Thelwall chose to support the cause of reform by using considerably more popular and accessible genres for the communication of his political thought than The Peripatetic ever was. He wrote and published political songs, poems, allegorical stories and even texts of political theory taking the forms of letters or lectures. In doing so, Thelwall was elaborating on modes of communication already well established in the popular mind, which made them particularly effective as contributions to radical political life. ${ }^{31}$ While it would be too strong to claim that the specific audiences and purposes of these songs, poems and stories were uniform, they do illustrate well the development of Thelwall's thought on equality and his related practice of more inclusionary politics.

31 Mark Philp, 'The Fragmented Ideology of Reform,' in The French Revolution and British Popular Politics, ed. Mark Philp (Cambridge: Cambridge University Press, 1991), 76. 
Consider, for example, the song 'News from Toulon', initially written for a public composed of members of the London Corresponding Society. Thus the primary target for such a text was an audience of hardened reformists usually coming from an artisan background. In this context, it would not have been the primary goal of songs such as 'News From Toulon' to convince the audience of the necessity or desirability of reform. Rather, they would serve to raise the morale of members of the assembly and strengthen a sense of community. Thelwall does this, for example, by mobilising a radical trope mocking Burke, and describing 'a wondrous transformation' by which 'Lo! A Swinish Multitude were chang'd to men and heroes' ${ }^{32}$ Songs like this one would also be used to amuse the audience by ridiculing their adversaries. Thus, the particularly sarcastic last verse, bringing to a close Thelwall's mocking the failure of the English troops who lost their strategic force in Toulon, and his genial celebration of the triumph of the revolutionary movement in France:

Thus ends, the woeful tale, good friends, of Gotham's expedition; A tale must fill each loyal breast with sorrow's sharp attrition, And so God save kings, priests, and lords, and princes altogether, And shield them, in these changeful times, from lapstones, lasts, and leather. ${ }^{33}$

32 John Thelwall, 'News from Toulon; or, the Men of Gotham's Expedition. Sung at the Globe Tavern, at the General Meeting of the London Corresponding Society' in Michael Scrivener, ed., Poetry and Reform: Periodical Verse from the English Democratic Press, 1792-1824 (Detroit: Wayne State University Press, 1992), 113-115, lines 6-9.

33 Ibid., lines 56-59. 
Yet the story of 'News From Toulon' does not end here. After the Treason Trials, Thelwall reprinted this song in The Tribune (1795), where he also published the edited texts of his lectures. ${ }^{34}$ As printed media, the songs could reach a different and probably wider audience than the LCS membership. Indeed, Thelwall boasted an attendance of four to seven hundred at his lectures and one thousand copies of the three-pence standard edition of The Tribune were circulated. ${ }^{35}$ It is in this context of a wider distribution, in a relatively cheap publication that they could be used not only to amuse and delight an already sympathetic audience, but also to educate and, to borrow Jon Klancher's graceful turn of phrase, 'to bind one reader to another as audience' and thus help (re)construct and solidify a popular reformist base in the context of increasing governmental repression. ${ }^{36}$ More broadly, and yet perhaps more crucially, Thelwall brings to the fore in this song his conviction that it is possible for members of the lower classes to emancipate themselves: the 'swinish multitude' is really 'chang' $\mathrm{d}$ to men and heroes.'

This is a relatively new view for Thelwall though it becomes one of the stronger bases for his political activity starting in late 1793 and until at least the later part of the 1790s. Popular education and emancipation become central, for instance, in the story of King Chaunticlere, one of Thelwall's attempts to both educate and persuade individuals

34 Michael Scrivener, 'John Thelwall and Popular Jacobin Allegory, 1793-95,' ELH 67, no. 4 (2000): 951-952.

35 See the introduction to the excerpts of The Tribune in Lamb and Wagner, Selected Political Writings of John Thelwall, vol. 2, 2. In addition to the three-pence standard edition, there was a 'fine edition' priced at sixpence.

36 Klancher, The Making of English Reading Audiences, 1790-1832, 100. 
who were not members of the London Corresponding Society. Here again, he not only makes use of a popular mode of communication, but also of particularly wellestablished popular tropes. This allegorical story was first recounted at a meeting of 'the Capel Court Society [a well-known London debating society], during the discussion of a Question, relative to the comparative Influence of Love of Life, of Liberty, and of the Fair Sex, on the Actions of Mankind,' in late $1793 .{ }^{37}$ In such a venue, Thelwall would have most likely tried to convince (as well as amuse) a diverse audience in terms of class, gender and politics ${ }^{38}$ while the printed version, published by Daniel Isaac Eaton, would have reached a wide popular audience.

Appropriately, he begins his speech by responding to his predecessor on the stage. Using the example of a tortured slave protecting himself from a fatal blow delivered to relieve him of his misery, the previous speaker had argued that the love of life was a greater determinant in human actions than the love of liberty. Against this, Thelwall deploys a scientific argument based on the notion of habitual motion: the slave's movement to protect himself was not an action emerging from his will, determined by the love of his life, but simply by a habit. Drawing on this argument, Thelwall goes on to suggest that the slave's action is comparable to that of 'men, of base and abject minds, who have long been used to cringe and tremble at the names of kings

37 John Thelwall, 'King Chaunticlere; or the Fate of Tyranny,' in Lamb and Wagner, Selected Political Writings of John Thelwall, vol. 1, 33-36, 33.

38 See the introduction in Donna T. Andrew, London Debating Societies 1776-1799 (London: London Record Society, 1994), http://www.british-history.ac.uk/source.aspx?pubid=238. Accessed 7 September 2016. See also Mary Thale, 'London Debating Societies in the 1790s,' The Historical Journal 32, no. 1 (March 1, 1989): 57-86, 57. 
and lords. ${ }^{39}$ To illustrate this point and to show how individuals can free themselves from such a habit, Thelwall mobilises a well-known figure of popular culture: the gamecock Chaunticlere, of Chaucerian fame.

In Thelwall's allegorical fable, King Chaunticlere (representing George III) is a tyrannical gamecock 'fond of foreign wars and domestic rebellions,' and making life in the barnyard miserable. ${ }^{40}$ The narrator, as a consequence, decides to kill the gamecock, though to do this he has to fight 'some aristocratic prejudices,' a consequence of his 'education,' which cause him to look 'with considerable reverence, upon the majestic decorations of the person of king Chaunticlere. ${ }^{41}$ This story stands in sharp contrast with the narrative of The Peripatetic, where, as we have seen, labouring individuals cannot free themselves from the consequences of their circumstances. On the contrary, this fable suggests instead that they, like the narrator (a farm-boy), can effectively become agents of change. In a reversal from the situation in early 1793, Thelwall now has working class individuals speak and act according to higher principles, in this case, the love of liberty.

Thelwall's use of popular culture, both oral and print, to express his political thought in order to agitate as well as educate the lower-classes of English society constitutes a development of and, in some ways, a departure from his ambiguous position in The Peripatetic. Accordingly, Thelwall's target audience changes from the relatively educated and materially comfortable readers of The Peripatetic to the artisans

39 Thelwall, 'King Chaunticlere,' 34.

40 Ibid.

41 Ibid., 34-35. 
and urban labourers populating, for example, the London Corresponding Society. This change of a target audience and a concern for accessibility informs the choice Thelwall makes concerning the format of his most important theoretical contribution to the debates of the 1790s: the Rights of Nature, Against the Usurpations of Establishments (1796). In that work, he advocates what he sees as the inalienable right of poor individuals to independence, ${ }^{42}$ and he addresses this text to them, the title page of the work indicating that the text is written as 'a series of letters to the people of Britain.' Of course, one might see this only as a rhetorical point, but Thelwall's publishing practice here is what truly made the text not only addressed, but also available to 'the people.' Thelwall's Rights of Nature were planned in the form of several pamphlets. This not only could keep the price of individual issues relatively low - as low as two shillings but the very plan for the division of the text into different independently printed parts

42 For a more detailed discussion of this work, see: Gregory Claeys, 'Introduction,' in Gregory Claeys, ed., The Politics of English Jacobinism: Writings of John Thelwall (University Park, Pa.: Pennsylvania State University Press, 1995), xiii-lviii, especially xlvlv. For a broader discussion of Thelwall's political theory and its sources, see: Iain Hampsher-Monk, 'John Thelwall and the Eighteenth-Century Radical Response to Political Economy,' The Historical Journal 34, no. 1 (March 1, 1991): 1-20; chapter 7 in Gregory Claeys, The French Revolution Debate in Britain: The Origins of Modern Politics (Basingstoke: Palgrave Macmillan, 2007). See also: Robert Lamb, 'Labour, Contingency, Utility: Thelwall's Theory of Property,' and Georgina Green, 'John Thelwall's Radical Vision of Democracy,' both in John Thelwall: Radical Romantic and Acquitted Felon, ed. Steve Poole (London: Pickering \& Chatto, 2009), 51-60, and 71-81 respectively. 
would make it easier for groups of people to share the burden of the costs between themselves, and over time. ${ }^{43}$

However, the most obvious, and perhaps the most important way in which Thelwall develops his politics and his practice as an egalitarian political thinker, is in his activity as a lecturer. His audience varied importantly over time, though it remained diverse in terms of class and gender throughout the period. As a member of the London Corresponding Society, and lecturing in that context, Thelwall would have been able to reach out to 'the self-educated journeyman [...], the printer, the shopkeeper, the engraver or the young attorney' as well as the 'older working-class communities - the waterside workers of Wapping, the silkweavers of Spitalfields, the old dissenting stronghold of Southwark. ${ }^{44}$ However, his later Tribune lectures saw an increase in the middle class component of the audience as attendance became more expensive. Nevertheless, throughout the period, transcripts of the lectures were available in the form of pamphlets both at the lecture house, and in Daniel Isaac Eaton's printshop in Newgate Street. One thousand copies of the lecture were sold at three pence each, which suggests a potential readership of several thousands through loans and circulation after the sale.

Thelwall's lectures covered a broad variety of topics, ranging from the government's budget, to history and philosophy. What they all had in common, however, was their powerful rhetorical style, their instructive purpose, and their ability

43 See the title page of John Thelwall, The Rights of Nature, Against the Usurpations of Establishments. (London \& Norwich: H. D. Symonds \& J. March, 1796).

44 E. P. Thompson, The Making of the English Working Class (London: Penguin Books, 1991), 23. 
to draw together elements from philosophy, history and current events to advocate political reform as well as agitate and educate the broadest possible segment of the population. The lectures are also interesting in the way that they articulate tropes, figures and discourses associated with the traditions of civic humanism (such as Machiavelli) and English Republicanism (such as the idea of the Norman Yoke, and the figures associated with the Civil War), as well as more contemporary views, such as those expressed by William Godwin and Thomas Paine. In short, the lectures embody Thelwall's critical project, the constructive dimension of his politics, and his concern for the education of the working classes, so that they can emancipate themselves. ${ }^{45}$

The chief reason for Thelwall's adoption of this new view of the abilities of the broad British public is probably be the changing nature of his political circle over the year 1793, as he pursued his activities despite increasing governmental repression. Shortly after he had joined Major Cartwright's respectable radical Whig Society of the Friends of the People, Thelwall witnessed its suppression. This led him eventually to join the "essentially plebeian and much larger London Corresponding Society." ${ }^{46}$ In this social context, he would have seen first hand that a large number of members of the lower and lower-middle classes were able to formulate what he would consider sound political judgements, provided they had access to the relevant information.

Access to information, then, becomes a crucial dimension of Thelwall's political concerns, more so even as the 'Gagging Acts' suppressed radical discourse. But it is not

45 For more on Thelwall's lectures and The Tribune, see the introduction in Claeys, The Politics of English Jacobinism, xxiv-xxvi, see also Lamb and Wagner, Selected Political Writings of John Thelwall, vol. 1, xiv-xvi; vol. 2, 1-3.

46 See Claeys' introduction to The Politics of English Jacobinism, xviii-xix. 
only the 'Gagging Acts' that matter. In The Rights of Nature, Against the Usurpations of Establishments, Thelwall forcefully condemns 'the impediments thrown in the way of a cheap, and therefore general circulation of knowledge by the duties on paper, stamps on newspapers, advertisements, and the like. ${ }^{47}$ The ability of the British public to access information is also at the centre of Thelwall's justification for severing his links with the London Corresponding Society. Being part of an association proved to be a liability and led him to be tried (and acquitted), removing him - however temporarily - from his platform as a popular educator. It was in that role, rather than in that of the association member, that Thelwall seems to have thought his "individual exertions could be more important to the cause of liberty." ${ }^{, 48}$ More generally, Thelwall's combination of oral and print cultures, his use of popular forms and forums, the multiplication of genres he deploys, and his attention to the prices of his lectures and publications reflect his commitment to creating spaces and opportunities for political information to circulate within a broader public.

And yet, while this is a significant development in Thelwall's theoretical and practical egalitarianism, it was not unproblematic and seems to have caused Thelwall some anxiety. He was painfully aware of the power he had as a speaker, writer, and in some way, as a representative of a segment of the population. This first source of anxiety was compounded, as Jon Mee has shown, by a further anxiety concerning the

47 Reprinted in Claeys, The Politics of English Jacobinism, 399.

48 See Thelwall's pamphlet Citizen Thelwall, Fraternity and Unanimity (London, 1795), reprinted in Lamb and Wagner, Selected Political Writings of John Thelwall, vol. 1, 97-99, 99. 
potentially explosive 'enthusiasm' and irrationality of the crowd in attendance. ${ }^{49}$ As a consequence, at the outset of the first 1795 lecture 'On the Moral and Political Influence of the Prospective Principle of Virtue' (later published in The Tribune), Thelwall insists rather heavily:

citizens, though I shall speak my opinions with that firmness which results from the conviction of my own mind, yet I warn you again - I have warned you frequently, but I cannot too often, that I do not deliver opinions from this place for you to adopt them without examination. I advance them for your serious investigation, and I warn you again and again, to beware of that prejudice which, from having formed attachments to individuals, leads us to take for granted all they say. I most seriously recommend you to be as averse to a Pope in Beaufort Buildings as to a Pope at Rome. ${ }^{50}$

In choosing to lecture, Thelwall therefore strikes a compromise between his reinforced egalitarianism, now including a robust belief in the possibility of mass popular education, and his anxiety, shared with Godwin, over the potentially destructive effects of rhetorics in the crowded lecture hall. However, this latter point is not simply a residual prejudicial distrust of the masses that Thelwall might still have - though that may still have been a part of it; ${ }^{51}$ it is also a self-reflective understanding of the hierarchy that the pulpit creates, and of the power of the speaker over the audience. In short, it is an understanding of the inequality of status that follows from the form of the lecture hall and of one of its consequences: if the speaker's power remains unchecked,

49 Mee, "The Press and Danger of the Crowd': Godwin, Thelwall, and the Counter-Public Sphere,' 92-93; See also: Fairclough, The Romantic Crowd, 118-119.

50 Reprinted in Claeys, The Politics of English Jacobinism, 89.

51 Fairclough, The Romantic Crowd, 119. 
that inequality might lead not to enlightenment and the growth of knowledge in individuals of the lower classes, through the operation of their private judgment, but rather to their uncritical adoption of propositions made from the pulpit. Should the lecture's audience follow the 'Pope in Beaufort Buildings' Thelwall feared he might become, and following his thought, it is doubtful that the 'wondrous transformation' that changes the 'Swinish Multitude' into 'men and heroes' would occur.

\section{Godwin's Reorientation: the Politics of the Author-Reader Relationship}

Let us return to Godwin's Considerations on Lord Grenville's and Mr. Pitt's Bills Concerning Treasonable and Seditious Practices, and Unlawful Assemblies, which started the Godwin-Thelwall controversy. A large part of the text consists of a presentation and defence of what Godwin considers to be the channels of effective communication. He sees them as threatened from all sides: by political associations, by the political lecturer, and by the government's censorship of speech and writing in the public sphere.$^{52}$ For Godwin, it is the lack of effective communication that generates the potential for both revolutionary and reactionary violence, and this, in turn fundamentally undermines the cause of reform and the progress of truth and equality.

Highlighting Godwin's critique of Thelwall's practice is crucial in order to understand Godwin's own attempt at renegotiating the terms of the communication of political thought. This critique revolves around what Godwin considered to be the problematic and necessary consequence of what Mary Fairclough has called 'the

52 The Considerations are reprinted in Godwin, Political and Philosophical Writings of William Godwin, vol. 2, 125-162. For these points, see Ibid., 129-133 and 138-146. 
sympathetic identification between orator and audience' in the lecture hall. ${ }^{53}$ Following Godwin, Thelwall's lectures - and all other similar platforms - give more weight to fiery rhetoric than to the dissemination of propositions to be reviewed by a critical eye, regardless of Thelwall's faith in the self-disciplining processes of the popular crowd. ${ }^{54}$ Essentially, this is a repetition and elaboration on Godwin's treatment of large associations, where private judgment is impeded because of the way 'the sympathy of opinion catches from man to man,' tending to lead to riot rather than the quiet pursuit of truth and reform. ${ }^{55}$

However, this is not the only danger Godwin sees in the practice. In his view, the orator's love of fame and his desire to win the approbation of the crowd may well bring him to compromise the justness of his principles, even though 'the political lecturer' might 'commence his career with uncommon purity of intentions.' ${ }^{56}$ This is especially the case, for Godwin, if the lecture is held in front of a 'mixed and crowded audience', where there are 'no persons of eminence distinction and importance in the country [...] to temper their efforts. ${ }^{57}$ It is this final comment that has led critics to ascribe a very strong form of elitism to Godwin, and has led Isaac Kramnick, among others, to contrast this elitism with the inclusivity of Thelwall's democratic politics, and to go on to accuse

53 Fairclough, The Romantic Crowd, 118.

54 Godwin, Considerations on Lord Grenville's and Mr. Pitt's Bills, 129-133

55 Godwin, Political Justice (1793), 118.

56 Godwin, Considerations on Lord Grenville's and Mr. Pitt's Bills, 132

57 Ibid., 129-130. 
Godwin of being an objective ally of the reaction. ${ }^{58}$ There is undoubtedly some truth to this contrast, although Mark Philp has justly remarked that our reading of Godwin's Considerations has often been uncharitable because of the historiographical construction of our understanding of the polarization of the 'Revolution debate. ${ }^{59}$ In Philp's view, in the Considerations, Godwin is trying to articulate a position that resists the polarization of the debate, and keeps in line with the 'principles' of the popular reform movement, while condemning the 'means of progress' it deploys. ${ }^{60}$ However, I will suggest that there is something more deeply philosophical and less strictly instrumental in Godwin's rejection of the political activities of Thelwall and the London Corresponding Society, which has to do with the nature of power relations in communicative actions.

As we have seen, when Godwin rejects the lecture as a format for political education, he does so on the grounds that the orator has a certain power over his audience - a power to excite or instruct the crowd - while the speaker is, at the same time, under the power of the crowd. More specifically, for Godwin, the power of the orator over the crowd only seems problematic if there is the counteracting power of the crowd over the orator: that is, if the orator can be enticed by his love of fame, and therefore starts exciting the crowd's passion rather than enlightening his audience. ${ }^{61}$ This can be contrasted with the operation of power through the reading and writing of

58 Kramnick, 'On Anarchism and the Real World.'

59 Philp, 'Godwin, Thelwall, and the Means of Progress,' 63-64.

60 Ibid., 71.

61 Godwin, Considerations on Lord Grenville's and Mr. Pitt's Bills, 132-133. 
books. Indeed, this should cause no problem, because of the distance between the speaker - the author - and his audience. My claim here is that by the mid-1790s, Godwin was acting along these lines, or, to put it another way, he was starting to problematise the assumption of power by the author over the reader. We can track this shift by looking at Godwin's changing writing style.

Though he continues to work on updated editions of the Enquiry Concerning Political Justice, he complements that work with a novel, Caleb Williams (1794), and a book of essays, The Enquirer (1797), both of which follow a significantly different model of communication, and imply a much more egalitarian relationship between reader and writer. Furthermore, these texts are designed for a larger audience than Political Justice, which suggests that Godwin was also rethinking, if only in a relatively minor way, the elitism of the positions he expressed in Political Justice. In the initially unpublished preface to Caleb Williams, Godwin wrote:

The following narrative is intended to answer a purpose more general and important than immediately appears on the face of it. [...] It is now known to philosophers that the spirit and character of government intrudes itself into every rank of society. But this is a truth highly worthy to be communicated to persons to whom books of philosophy and science are never likely to reach. [...] If the author shall have taught a valuable lesson, he will have reason to congratulate himself upon the vehicle he has chosen. ${ }^{62}$

Godwin contends here that political and philosophical truths can, and should be communicated immediately to the less-well educated members of society, rather than

62 William Godwin, Caleb Williams, ed. David McCracken (Oxford: Oxford University Press, 1998), 1-2. 
passing by the slower process of dissemination primarily through works of philosophical enquiry and the persuasion of other highly-educated thinkers. However, he has also found an appropriate way to do so: fiction, meant to be read individually, leaving the final determinations to the agency of the reader.

Still, one should be wary to not over-interpret this move toward inclusivity. A novel was not generally accessible to, or indeed designed for a lower-class audience. Moreover, even as Godwin dabbed into the more popular art of political theatre, submitting the revised version of his 1790 play St Dunstan to Covent Garden, it was only because the theatre offered a particularly constrained medium for political communication. ${ }^{63}$ Lastly, as David O'Shaughnessy demonstrates, both the play and the novel's educational dynamics reflect 'the relatively sharp distinction Godwin drew between the educated elite and the uneducated general public at this point in the 1790s. ${ }^{64}$ As the preface to Caleb Williams indicates, the novel is a 'vehicle' for truth that takes the form of a 'performance' (the novel) that 'ought to be characterised' by 'interest and passion. ${ }^{65}$ The novel thus brings the truth out from the circle of the philosophers who have the capacity to strike it out through rational debate and hands it down to the uneducated public by an appeal to the passions, since an uneducated public cannot be expected to reason adequately.

63 David O'Shaughnessy, 'Caleb Williams and the Philomaths,' 444. On the special character of the theatre, and the connections between Caleb Williams and St Dunstan, see also the introduction and first two chapters in David O'Shaughnessy, William Godwin and the Theatre (London: Pickering \& Chatto, 2010).

64 O'Shaughnessy, William Godwin and the Theatre, 51.

65 Godwin, Caleb Williams, 1, my emphasis. 
Caleb Williams nevertheless marks the beginning of Godwin's deeper reconsiderations of his work and philosophy, as the Considerations and the 'Gagging Acts' mark his retreat from public debate. As Mark Philp has shown, parts of Caleb Williams already indicate Godwin's shift away from a strict rationalism in communication to a style more open to sentiment, sensibility, and rhetorics, in the service of justice. ${ }^{66}$ This informs his revisions of the Enquiry Concerning Political Justice, where, from the second edition onward, the idea that truth necessarily prevails over error takes on a new condition: it is only when 'truth' is 'adequately communicated' and no longer simply 'exhibited,' that it is omnipotent. ${ }^{67}$ This shift also informs Godwin's choice of form and style in his subsequent work, the collection of essays entitled The Enquirer.

Unlike the doctrines of the Enquiry Concerning Political Justice, then, the essays of The Enquirer are 'presented to the contemplative reader, not as dicta but as the materials of thinking,' and are to be appropriated by the reader so that the 'hints of enquiries' present in each of the essays can be 'cherished to maturity.' In addition, Godwin suggests in the preface to The Enquirer that political reform is ultimately linked with the 'humbler walks of private life', as well as with 'intellectual and literary refinement' and 'the cultivation of miscellaneous enquiries,' since they both 'amusement and instruction. ${ }^{96}$ For Godwin, in 1796-7, progress is no longer a matter of a grand philosophical scheme that is to be applied in order to arrive at political reforms.

66 Philp, Godwin's Political Justice, 116.

67 The variant is noted in Godwin, Political and Philosophical Writings of William Godwin, vol. 4,43 .

68 Ibid., 77-79. 
Instead, social, moral, and political reform emerge from the ground up, as the reader pursues an enquiry bearing a more or less indeterminate conclusion, on relatively familiar and relatable subjects, and with the assistance - and perhaps sometimes the guidance - of the author.

There are two sources for this revised position. The first is related to the development of Godwin's thought in the wake of the French Terror, and the failure of 1790s radicalism. Godwin reaffirms, with more conviction, that he perceives revolution and violence to lead to the dissolution of society. This is echoed in the preface to The Enquirer. For Godwin, the English Jacobins - himself included - 'were somewhat too imperious in their tone.' And thus, 'something [...] that savoured of barbarism,' of an attempt to conquer the minds of their audience, rather than persuade and accompany them. ${ }^{69}$ His account of social change, in the second and third editions of Political Justice, thus emphasises less the production of truth by a few enlightened individuals who might then try to act as a revolutionary vanguard - but rather on its dissemination on the ground. As Mark Philp puts it, Godwin, from 1796 on, is sturdy in the belief that 'when the people are ready for change, then change will occur.' ${ }^{70}$

The second source, and possibly the most important, lies in Godwin's new considerations on pedagogy, themselves the object of many of The Enquirer's essays. ${ }^{71}$

69 William Godwin, The Enquirer. Reflections on Education, Manners and Literature. In a Series of Essays (1797), reprinted in Political and Philosophical Writings of William Godwin, vol. 5, 77-289. The quote here is from the preface, Ibid., 78.

70 Philp, Godwin's Political Justice, 133. See also Ibid., 196.

71 For a more synthetic view of The Enquirer and Godwin's educational thought as a whole, see: Pamela Clemit, 'Godwin's Educational Theory: The Enquirer,' Enlightenment and 
Though the essays on pedagogy are largely concerned with the education of children, Godwin's reasoning on the relationship between the pupil and the tutor can be, to some extent, generalised to encompass students of any age, givenGodwin's concern for the dissemination of truth throughout the population. Godwin continually suggests in The Enquirer that tutors should treat their pupils "as much as possible" as genuine equals. ${ }^{72}$ They are not to be viewed as recipients for knowledge, imparted from authority, but as individuals endowed with powers of reasoning and who ought to "regard their actions as the actions of moral and intelligent beings." ${ }^{, 73}$ Furthermore, in an essay entitled 'Of the Obtaining of Confidence,' Godwin explicitly advocates treating pupils as equals, and, that tutors 'should discover a genuine sympathy in' their students' 'joys and sorrows. ${ }^{74}$ It is from this position of equality and sympathy for the specific conditions of the student that Godwin considers education to be fruitful. If we then consider that students may also be adults, and perhaps readers of The Enquirer, what follows is Godwin's construction of a very different kind of relationship between author and reader than that implied in the preface to Caleb Williams, where the author makes the novel a 'vehicle' for a truth already discovered, or than that of Political Justice where truth is simply communicated to a selected few.

Dissent 12 (1993): 3-11; and more recently Gary Handwerk, “Awakening the Mind': William Godwin's Enquirer,' in Godwinian Moments from the Enlightenment to Romanticism, ed. Robert Maniquis and Victoria Myers (Toronto, ON.: University of Toronto Press, 2011), 103-124.

72 Godwin, The Enquirer, 133.

73 On these points see for example Godwin, The Enquirer, 85, 131.

74 Godwin, The Enquirer, 134. 
Furthermore, Godwin's distinction between the 'moral' and the 'tendency of a text', and the primacy of the latter over the former, reinforces the position and agency of the reader in contrast with that of the author. 'The moral of any work,' Godwin states,

may be defined to be, that ethical sentence to the illustration of which the work may most aptly be applied. The tendency is the actual effect it is calculated to produce upon the reader, and cannot be completely ascertained but by experiment. The selection of the one, and the character of the other, will in a great degree depend upon the previous state of mind of the reader. ${ }^{75}$

This distinction and its implications have been explored at varying lengths by Pamela Clemit, Tilottama Rajan, and David O’Shaughnessy. Clemit and Rajan, who are primarily interested in this distinction in the context of Godwin's historical novelwriting, connect the moral of a text with an established authorial intention, contrasting it with the tendency, which is the product of specific interactions between the text and individual readers. ${ }^{76}$ In contrast, David O’Shaughnessy, whose interest lies primarily in Godwin's work as a playwright, argues that the distinction is less obvious, and that the relationship between the moral and tendency of a text is more intricate than is often recognised.$^{77}$ In his reading, the moral is not necessarily a product of authorial intention, rather, it is the 'generally agreed ideological reading of a text' by different groups of readers, and is as a consequence negotiated between the readers' own views and the text 75 Godwin, The Enquirer, 139.

76 Pamela Clemit, The Godwinian Novel: The Rational Fictions of Godwin, Brockden Brown, Mary Shelley (Oxford: Clarendon Press, 1993), 76; Tilottama Rajan, 'Wollstonecraft and Godwin: Reading the Secrets of the Political Novel,' Studies in Romanticism 27, no. 2 (1988): 223-224.

77 O'Shaughnessy, William Godwin and the Theatre, 25. 
they read. From this follows that a text may be found to have several contradictory morals, depending on its readership, and it may well be that none of these correspond to 'the moral contemplated by the author. ${ }^{97}$ The tendency exists in relative autonomy from the moral of the text, in relative autonomy from authorial intention, but is nevertheless also determined by 'the spirit in which' a text is approached by its readers. ${ }^{79}$

While the exact implications of Godwin's distinction are beyond the scope of this paper, the crucial point is that whichever way one looks at it, the emphasis in The Enquirer is on the possibility, and even need to allow readers to produce their own meanings and find truth through their creative interaction with the text, rather than through the kind of top-down didacticism implied in the preface to Caleb Williams, and more generally in Political Justice.$^{80}$ In short, with The Enquirer, Godwin recalibrates the relationship between author and reader into a co-operative, roughly egalitarian and productive one, carried as a metaphorical conversation between the reader and the author through the medium of the text, but emphasising the private judgment and agency of the reader over the arguments and rhetoric of the author.

\section{Conclusion}

By complementing an analysis of the texts produced by William Godwin and John Thelwall in the mid 1790s with considerations on how and to whom they were speaking, I have tracked important changes in the operationalisation of their versions of egalitarianism. Both authors, I have argued, begin with a strong egalitarian position, but

78 Godwin, The Enquirer, 139.

79 Ibid., 141; see also O'Shaughnessy, William Godwin and the Theatre, 27.

80 On this point, see also: McCann, Cultural Politics in the 1790's, 62. 
have a negative view of the abilities of a broad British public to reason adequately on political and moral issues. They were therefore primarily interested in generating change from the top down, from the élite down to the rest of the population, and consequently - tended to address a highly educated audience, at the expense of the majority of the public, despite their egalitarianism. This tension is partly resolved in their later thought, as expressed through their writings and activities after 1793.

Thelwall proceeded by taking on a much broader audience, and operated though not without any qualms - as both the educator and the mouthpiece of the radical labouring class. In this way, he acted more consistently with the political egalitarianism that underlies his thought. Moreover, this was consistent with the belief he had formed by late 1793 of the ability of members of the working classes to emancipate themselves, assuming they had access to the right kind of information. This revision, I suggest, is a consequence of changes in the sociology of Thelwall's political circle, as he moved from the genteel Society of the Friends of the People to the London Corresponding Society, following the heavy-handed repression that fell on the former. From this arose a separate problem, and a different kind of inequality: that of the hierarchical relationship between the speaker and the audience. While this caused him some anxiety, he eventually considered it to be an acceptable compromise, and lectured far and wide in London and the rest of the country.

For Godwin, this was unacceptable: the lecture hall generated too many problems linked to the different relationships of power that reigned over the speaker/audience pair. Acting on this problem, he attempted first with Caleb Williams, and then more successfully with The Enquirer to reconfigure the relationship between 
the author and the audience, by designing texts that generate the possibility for egalitarian, constructive dialogue between the author and the reader / audience. This, I have argued, was not only a consequence of Godwin's revised views on social change and their emphasis on appropriate political communication, following the French Terror and recent political events in Britain - but also of Godwin's renewed interest in pedagogy.

Understanding the dynamics of Godwin and Thelwall's egalitarianism, from the point of view of their generic choices provides a new perspective on their falling out. It was not, I have argued, simply a matter of disagreement concerning the means of progress. Rather, it was a disagreement running deeper in the recesses of both authors' views on the problems relating to the power relations between the speaker - or the author - and their audience, and the operationalisation of political equality in society. Even though Thelwall still seems to me to have been more successful in acting on his egalitarian principles than Godwin, my analysis of Godwin's slowly shifting use of different genres suggests that he was aware of some of the problematic aspects of his own thought and practice with regards to the equality of individuals in the context of political education. More than simply being aware of these problems, Godwin acted as an author to try and resolve some of them. Though he undoubtedly remained something of an elitist, he started operating on considerably more egalitarian foundations in his production of texts, and in his understanding of their reception. 